\title{
SOCIAL ROLE OF THE WALL: THE DOMESTIC VERNACULAR ARCHITECTURE OF SOUTH INDIA
}

\author{
ANJALI SADANAND ${ }^{2}$, RAMASAMY VEERANASAMY NAGARAJAN ${ }^{1} \&$ MONSINGH DEVADOSS $^{2}$ \\ ${ }^{1}$ Hindustan Institute of Technology and Science, India \\ ${ }^{2}$ Measi Academy of Architecture, India
}

\begin{abstract}
Meaning and symbolism consecrate the vernacular house. The vernacular house is a response to the environment visible in the investment of knowledge systems imbedded in its architectural fabric. The house becomes an agency of socio-cultural norms through the architecture language and materiality of its spaces and elements and in doing so the domestic house acts as a repository of intangible and tangible cultural heritage. The objective of this paper is to explore the role walls play in conserving this heritage. The paper will study the manner in which walls construct social realities by looking at the different roles they play, through an exploration of their character, materiality spatial, structural and social function. Theoretical frameworks espoused by Simon Unwin, Yatin Pandya and Julienne Hanson will be used to support the discussion. In order to illustrate the context of the wall in domestic vernacular architecture. The discussion will focus on a comparison of walls across four typologies of vernacular houses of varying size, spatial organization and materiality from Tamil Nadu, South India. It will be argued that in cases where change is present, modern materials have shifted the emphasis of a value system based on the significance of socio-cultural norms to that of socio-economic considerations which have resulted in subtle transformations. In other situations vernacular traditions as architectural strategies and devices are repeated in modern houses with the intention of continuing tradition. The wall is objectivized and finds its way in contemporary architecture as an artefact which through memory of association assures identity and continuity.
\end{abstract}

Keywords: wall, vernacular, gender, status, symbolism, layering.

\section{INTRODUCTION}

Architecture it is widely accepted creates and shapes relations between people. Vernacular architecture is embedded with socio cultural knowledge systems as intangible and tangible heritage present in tradition and beliefs and manifest in their physical realities. Glassie elaborates on this with respect to walls and technology. "With the act of physical alteration that calls into space, implying a past and a future, and with walls that divide space, at once including and excluding, architecture has happened" [1]. "Technology is a corollary of human existence. As life unfolds, every technological act brings changes in two great relations: the one that always connects the humans and nonhuman spheres and, the other that is built to connect people with one another" [1]. "Vernacular technology depends on direct connections: direct success to materials and direct connections amongst suppliers, suppliers and consumers who simultaneously shape landscapes, social orders and economic arrangements, while wealth circulates in the vicinity" [1]. A study of walls in domestic vernacular architecture will inform us about local traditions and lifestyle patterns and hint at the direction taken in terms of transformations due to the transmission of other technologies through modernization. On the one hand, there is a desire to inculcate new systems and on the other hand a desire to keep certain traditions alive. The paper will demonstrate this aspect through case studies, in a vernacular setting where there has been an adaption of "new" technologies, relative to time, and as a response to needs. It will show that in an urban setting vernacular heritage is objectified and features as motifs and artefacts. 


\section{DEFINITIONS}

The word "Vernacular" derives from the Latin "vernaculus" meaning domestic, "native" so the definition "native science of building" is really quite appropriate [2]. Oliver further elaborates his definition to say "in using the generally accepted phrase 'vernacular architecture,' I am embracing all the types of building made by people in tribal, folk, peasant and popular societies where an architect or specialist designer, is not employed" [2]. Included in the scope of vernacular architecture he continues to say "Although traditional village building has declined and the barriadas of Peru, the bustees of Calcutta or the favelas of Brazil are made from salvaged and scrap material, some architects have seen in the periurban squatter's passionate desire to build their own" [2]. "Vernacular architecture studies may in this way defined as the study of those human actions and behaviors that are manifest in commonplace architecture. "Vernacular architecture is a set of objects, the common buildings of a given place and time: as ensembles of buildings or vernacular landscapes, the products of a particular architectural community: as vernacular architecture studies, an approach to studying buildings as cultural manifestations" [3].

\subsection{Building type definitions based on materials}

"Those composed of short-lived materials-mud, sticks, grass-are defined as kaccha. (hindi for unripe raw incomplete) They contrast with pukka (proper, ripe, cooked. structures made to last, using more tenacious material-worked stone or timber, burnt bricks, lime plaster. Many combine several ingredients: Indian architects refer to them as semi-pukka" [4].

\section{THEORETICAL FRAMEWORK}

Paul Oliver and Rapoport put forth the connection between culture and material and construction as significant to vernacular Architecture. In Built to meet needs, Oliver states "The main purpose of the present collection is to consider the cultural factors that bear upon the subject" [2]. He makes references to material, construction techniques, plans etc. Talking about heritage he considers traditions which have been retained and are still in use. $\mathrm{He}$ comments, "Cultural traits and environmental contexts constituted the focus of vernacular tradition in buildings, which have often existed for centuries" [2]. "Undoubtedly, physical cultural and perceptual factors affect the degree of significance of certain features in form, structure, space use, or detail in buildings although changes over time are to be seen in most building traditions, the persistence of distinct building types and forms, of material resources and methods of construction and of space use and of associated value is undeniable" [2]. Oliver points out to aspects of tradition and transmission. "Traditions are sustained if they have meaning: they may be practical or symbolic" [2]. In reference to materials and technology, he says" innovation and change result from diffusion and experiment rather than from inducement and intervention" [2].

Rapoport in House Form and Culture in agreement with Oliver's, in House, Form and Culture suggests that socio-cultural factors override climatic factors and factors related to material and construction. Rapoport lists five socio cultural factors as "basic needs, family, position of women, privacy and social intercourse" [5]. He stresses on the significance of time, meaning and communication. Rapoport says that "vernacular design is achieved through the application of a system of shared rules. In effect vernacular design is best defined as being based on the use of a model with variations and differing from primitive design in the extent of variations. Since the model is shared and widely accepted, the resulting environment communicates clearly to their inhabitants" [6]. "Since in humans symbolic behavior generally is central and since artifacts, including buildings and settlements are one 
type of symbol which make concrete the immaterial, space less, timeless nature of values, meanings and life" [6]. Rapoport extends this understanding to the environment and provides us with a set of cues which he names as fixed and non-fixed elements to establish a system of non -verbal communication in which walls are considered as fixed elements.

Yatin Pandya in 'Elements of Spacemaking' suggests a framework for looking at architectural elements. He comments that walls are protective barriers and used in vernacular architecture also as storage. With respect to openings, he comments, "The door connotes an act of passage between two realms" [7]. Yatin Pandya in "Concepts of Space in traditional Indian Architecture' describes strategies used in Indian vernacular architecture. He elaborates on sequential space, as articulated in architecture, to engage with the body in the form of movement through a system layering which create spatial narratives and employ columns and walls as elemental to cater to their purpose. Layering, Yatin Pandya comments is a spatial strategy for preserving social hierarchy and ensuring security and privacy.

McMurtrie states "Semioticised spaces are spaces that we can reach and use as resources for a specific social purpose and as such they are social constructs. Only structured semioticised spaces are relevant to the semiotics of movement in space" [8]. Space is text and the readings and experience of space, as meaning, with respect to volume, solid, as in wall, materiality, light and texture create the narrative which concertize spatial experience.

Kulbushan Jain in 'Thematic Spaces' in the Indian context, reinstates the significance of the threshold as an important aspect of Indian traditional architecture and element of the façade wall.

Simon Unwin in 'Analysing Architecture' and the Wall talks about the different roles the walls play by illustrating different types of walls. Examples are seen in the wall as a marker, as a form of enclosure, loadbearing wall and the inhabited wall which contains space and, wall as frame.

Julienne Hanson in Decoding Houses comments that "The important thing about a house is not that it is a list of activities or rooms, but that it is a pattern of space, governed by intricate conventions about what spaces there are, how they are connected together and sequenced, which activities go together and which are separated out, how the interior is decorated, and even what kinds of household objects should be displayed in the different parts of the home" [9]. Hanson uses many parameters such as, relationship of house to street, control of entrance, placing of objects within the interior, relationships of specific activities to rooms and spatial variables such as visibility/permeability, insulation/sequencing categoric differentiation/relative position. These are used for analysis within the domestic interior and between the interior and exterior of the house. Social norms that dictate behavior patterns and privacy are significant to understanding traditional architecture and the three spatial variables enlisted by Hanson in decoding houses suggest a way of analysis. The three significant spatial variables she postulates are as follows. "Visibility/permeability: Visibility refers to whether or not the interior of the dwelling can be seen from the street, or to whether it is possible to see clearly from one part of the domestic interior into another" [9]. "Visibility is about whether space is used to manifest objects and behaviors or to conceal them. It tells us about the relative transparency or opacity of the domestic setting, a permeability, which refers to the amount of control exercised over the way in which it is possible to move from one space to another" [9].

Insulation/sequencing are the second pair of spatial variables. "By insulation is meant the degree of discontinuity, that is, the strength of the boundary, between rooms. Where insulation is plus, rooms may be separated by a partition, or perhaps face each other across an intervening space. A railing or line of columns, a change of floor level or ceiling height, or even by differences in surface appearance. Cupboards or stores may be used to add mass 
and to emphasize the boundary wall" [9]. Hanson argues that a low insulation value is attributed to spaces demarcated by "a railing or line of columns, a change of floor level or ceiling height, or even by differences in surface appearance" [9]. "Sequencing is defined as the way in which spaces are connected together into chains" [9]. Hanson continues to say "Where sequencing is plus, it is always necessary to go through one space to reach another, and minus sequencing means that spaces are one cell deep from a central circulation space" [9]. Categoric differentiation/relative position looks at "aspects of spatial organization which are not so much morphological - to do with the internal logic of the physical arrangement - as microcosm effects - to do with the way in which spaces acquire particular social identities which particular functions are assigned unambiguously to specific spaces within the home" [9].

A review of parameters for analysis can be listed as:

- Perception of the wall

— Size, form and material, elements

- Aesthetics

- Spatial arrangement - layering

- Structural aspects

- Openings

- Social and Symbolic function as material culture

- Aesthetics

- Types of walls

- Boundary, marker

- Inhabited wall

- Structural

- Barrier

- enclosure

- Parameters based on spatial variables

- Visibility/permeability

- Insulation/sequencing

\section{SCOPE AND LIMITATIONS}

The four house samples are of varying sizes and typology and restricted to Tamil Nadu. They include kaccha, and pukka houses of different time periods and settings.

\section{METHODOLOGY}

The houses to be studied will be studied in a specified order based on the understanding of aspects of vernacular architecture explained at the beginning. The first house is a traditional four hundred year old house, located in an Agraharam, which will introduce the social system related to houses. The second example will show a larger house of a different typology built with the fusion of colonial and the vernacular tradition, in a town, indicating the transmission of technology into the form and aesthetic detail of building elements, the third house will depict a 'progressive' vernacular house, but built in modern materials and with the vernacular tradition relating to measurements and perceptions and the last house will be an example of a tribal Toda hut illustrating the vernacular tradition in kacha construction in a natural setting. References will be made to other examples for points of comparison. The examples will be 
analyzed with respect to the above listed parameters. A table showing spatial variables will indicate values for spaces in all four types. 0 indicates the space is not associated with any activity while 5 will indicate the space is used only for a particular activity. A mid-value of 3 will indicate the space has many activities which change during different times of the day.

\section{DISCUSSION}

\subsection{House 1 - Type 1}

House 1 is located in a village close to Tanjore. It is an example of a typical Agraharam model house. Andre Beteille describes an Agraharam as "the Agraharam is where all the Brahmin houses are located" [10]. It is the center of their social life. Agraharams are usually built around a temple either by encircling it on three sides like a garland or form a linear street pattern with houses on either side facing east west and leading to a temple. Houses share a common wall with their neighbor. Every part of the house responds to a functional need which caters to their relevant social norms. The typical house is deep, spatially organized around a single or multiple courtyards and has a back door leading to an alley or land. The house is linear and space is sandwiched between two walls. The street houses only the same caste. Houses directly interface with the street. The street is an extension of the house. The street view is of a string of similar house facades which differ not in architectural language but in size as in their respective widths construct a wall enclosing the street which in its original context was an extension of the house. The house directly interfaces with the street. The street is an extension of the house. The facades of the houses construct a wall enclosing the street which in its original context was an extension of the house Caste separation was strictly maintained in traditional India and people of other castes communicated through the rear door. In a social milieu of strong hierarchies and differentiation the Agraharam house displays a spatial program which preserves social differentiation based on gender and hierarchy through a strategy of layering of space using walls to articulate reveal and conceal public, semi public and private spaces.

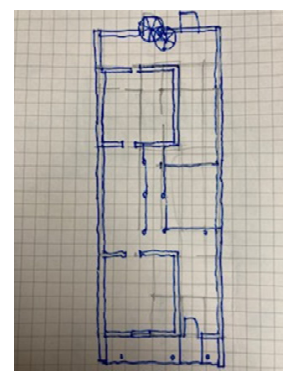

Figure 1: Plan of Type 1 house. (Source: Authors.)

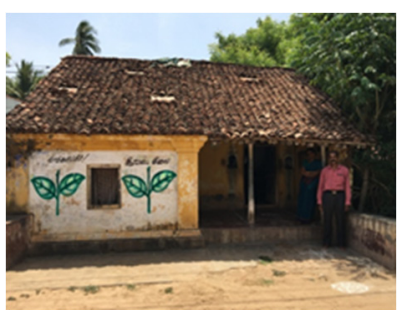

Figure 2: Elevation of Agraharam house. (Source: Authors.)

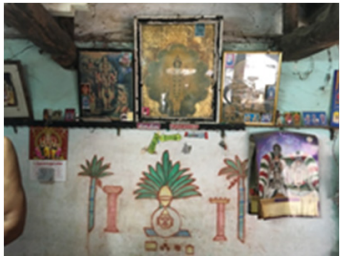

Figure 3: Interior wall showing deity. (Source: Authors.)

\subsubsection{Layering with respect to exterior}

The house façade consists of a Thinnai area. A break in the Thinnai facilitates a point of entry. Layering is seen in two locations: (1) with respect to the street and (2) with respect to 
the courtyard (Fig. 1). The house interfaces with the street via a Thinnai (Fig. 1). The first Thinnai, layer is demarcated by a raise in plinth and two low walls which protrude from the house façade and act as territorial markers and function as seats. They are called Thinnai. Social custom permits any passerby to sit on these low walls and the Thinnai demarcate public space. They are made of brick with plasterwork. The façade is divided into a wall which has one window, closed and shuttered and a second Thinnai which is semi-public in character and is covered and shaded, visible and permeable with a raised seating area. The raised area is designed for someone to sit on the floor from the street. Timber columns with carving on brackets support the sloped and tiled roof. As a boundary wall of the house, it corresponds to Simon Unwin's description of an inhabited wall. It is also a barrier as it insulates the house from the street with respect to socially screening the interior and in addition climatically creates a buffer zone to reduce the absorption of heat from the street. There is a haptic function to building elements. This space is multifunctional. Gender differentiation is followed as in the afternoon women visit each other using this space for social interaction while during the day men use the space and a bed can be placed here to catch the breeze. Beyond this space, internal layering is experienced in sequential placement of transition.

\subsubsection{Elements of facade}

Craftsmanship aside from being invested on the columns in Thinnai is focused on the front door. The architectural character in terms of carving and detail of columns, wall surface color and detail of the door give identity and reflect status of the house. The Thinnai rear wall is a backrest as is the columns. In some instances, a dado of paint on the wall corresponds to the portion of wall used as a backrest. Color and paintwork are used to create identity. The front door is aligned to the entrance of the second space and to the exit door beyond which leads to the alley. In the façade only one window is visible. The window is rarely opened ensuring privacy to the room. The front door is usually only five feet in height and one bends one's head when one's enters. The door frame is detailed with a carved overmantel over the door shutter usually decorated with the symbol of a deity. The carving and woodwork of the door follow a vernacular language of plank construction in locally available timber and with traditional craftsmanship and detail. Thresholds are symbolic and manifest fetishes, symbols which endow prosperity and keep off the evil eye. On either side of the door are two niches made into the wall which house lamps which will be lit when darkness falls. The front room, called camera is provided with a small window, closed at most times with timber shutters, and is dark. It the only room in the house with a small window overlooking the street and kept closed. In the interior, the wall of the main hall which has a picture ledge along which ancestral photographs are hung and in one area religious pictures of reigning deities serve as an altar for worship (Fig. 3). The wall itself is painted with iconography of symbols to which offerings and prayers are made. This imparts a sacred quality to the hall which results in taboos being maintained towards entry to the space for women during menstruation. Space is text. The wall itself in part becomes an object of ritual and symbolic in its use. The Hall is a primary social gathering space of the house.

\subsubsection{Layering in the interior}

An ante space leads to a colonnaded passage open to a courtyard. There are two rows of columns and as metaphoric walls the columns demarcate different zones ranging from public to private, profane to less profane and more important. Spaces in the houses are designated according to Hindu building norms called 'vastu.' There are two rows of columns which between them bound a transition space of low categoric value. The inner row of columns 
border a hall the family space of the house which is used for social functions and has therefore more significant social value attached to it. The columns are short with decorated capitals richness of detail in wood craftsmanship and reflects status (Fig. 1). The columns are more articulated than the outer row close to the courtyard reflecting the status of the thalavaram which is for general use. The spatial narrative created in the form of a sequential journey from public to semi public and private, through spaces of differing volume materiality light and articulation established through a system of layering characterize the architectural character of the Agraharam house. Walls are loadbearing and made of bricks set in lime mortar which keeps the house cool. The front door is aligned to a rear opening which leads to an alley and fields at the back of the house.

\subsubsection{Spatial variables}

Visibility is ranked low as the interior is not displayed to the street through alignment of front door (see Table 1). Categoric differentiation of spaces value is a neutral 3 (Table 1), as only kitchen and the front room have designated functions. The interior wall of the main hall which has a picture ledge along which ancestral photographs are hung in one area with religious pictures of reigning deities serve as an altar for worship (see Fig. 3). The wall itself is painted with iconography of symbols to which offerings and prayers are made. This imparts a sacred quality to the hall which results in taboos being maintained towards entry to the space for women during menstruation. Wall and Space are text. The wall itself in part becomes an object of ritual and symbolic in its use. The Hall is a primary social gathering space of the house. The house presents cues which are universal to the members and can be read and followed rigorously. In Rapoport's terminology walls act as fixed elements delivering a message which determines social behavior. In Gibson's terminology of affordances the wall in an Agraharam house is negotiated, adapted and transformed into every usable aspect to satisfy social needs. It is an architectural structural element, a component of enclosure, marker of territory, furniture, provider of social interaction and neighborliness and an object of ritual. It enacts its role within a set of codes acknowledged, accepted and read and understood by the people of its environment. Areas of taboo are maintained and respected even if they are not physically marked by territorial walls. The effect of the wall as a social barrier is felt even in its absence. The interior colonnades act as metaphoric walls dividing more profane areas from spaces of higher status. Common walls between courtyard and neighbor are barriers and high and do not encourage social interaction between neighbors but insulate the houses socially.

\subsection{House 2 - Type 2}

Type 2 house is the house of a gentleman of Marathi origin, who was adviser to the Thanjavur royalty and represents the bungalow type residence built in a town, more than 100 years ago, during the colonial period. It is set in a large ground of land, set back from the road and represents a fusion of colonial and the traditional model. It has a large hall typical to such houses of the period as suggested by Ananthalwar, in his treatise on Indian architecture.

The house can be divided into two zones, a public formal zone in front and a rear private zone organized around a courtyard.

\subsubsection{Layering}

A compound wall (Fig. 4), demarcates the property and an ornate entry set in the wall marks the entry point. There is a clear definition of public and private. The house unlike the 


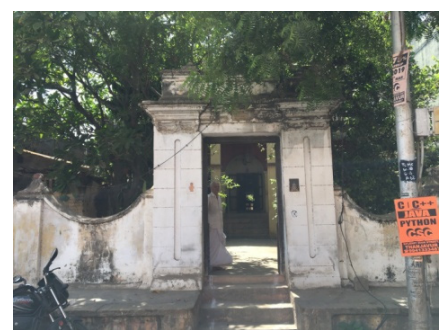

Figure 4: Entry to House 2. (Source: Authors.)

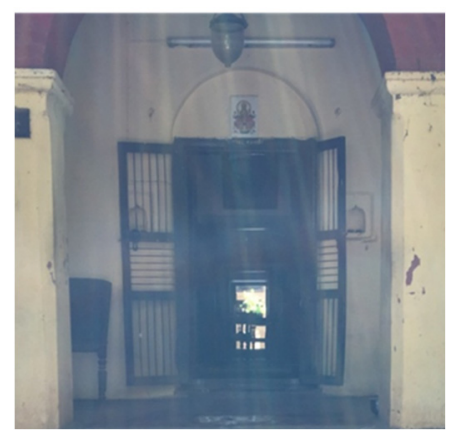

Figure 6: Showing arched entry, niches and colonial light fitting. (Source: Authors.)

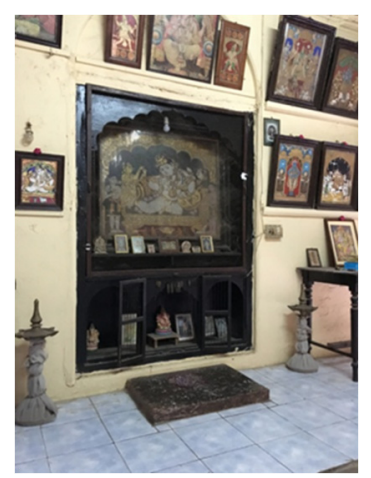

Figure 8: Niche with painting of deity and fire altar on ground. (Source: Authors.)

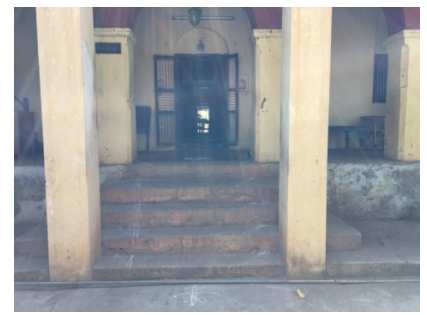

Figure 5: Thinnai in two layers. (Source: Authors.)

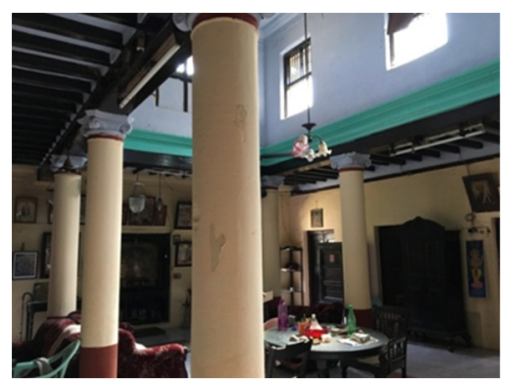

Figure 7: Interior hall showing colonial columns and clerestory. (Source: Authors.)

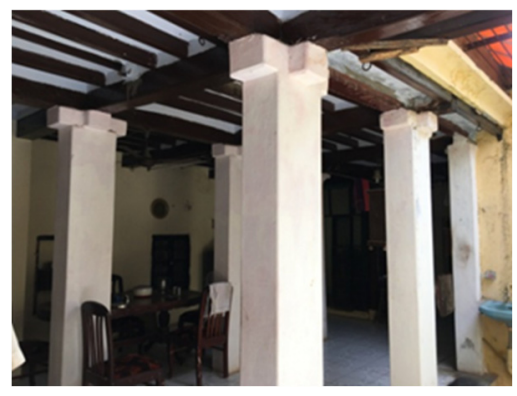

Figure 9: Columns in rear and private area. (Source: Authors.) 
Agraharam house is not permeable to the street. The compound wall delineates boundary as in territory and acts as a barrier protecting the house through which there is a single point of access. Unlike as in the Agraharam house, security is demanded by its setting as the cultural landscape is diverse. Type 2 demonstrates the use of layering as a tool for creating social differentiation primarily based on gender and status. There are two levels of Thinnai (Fig. 5), incorporated into the bungalow and separated by a change of level. Through a sequence of layers one enters the main house interior. The first layer is two storey high and is composed of structural brick piers. The second layer is made of arched openings set in a wall. Technology is used here to differentiate the two environments and reflect status, the higher Thinnai being reserved for people of higher rank. This space is a transition to the interior and a space restricted to men and outsiders of a rank who cannot be entertained in the reception hall in the interior. The front door (Fig. 6), aligns to the interior kitchen window on one side and the front entry in the compound wall on the other side. The window is a point of control. Past the front Thinnai one enters another transition space, before entering the hall. Windows flanking the entry open into the second Thinnai area. Windows are large and disclose the interior. The rooms and transition spaces 'insulate' the main central hall, which the most significant space and accessible from the outside through three intermediate layers The reception hall has a large central area covered by a clerestory roof which is delineated by a colonnade of circular columns with capitals which reference colonial buildings and further indicates transmission of colonial technology (Fig. 7). It can be mentioned here about the similarity of the columnar framed space used as a reception area to that in Vishrambaugh Wada in Pune of Maratha origin where the columns are made however, of timber. The front part of the house which represents the public image is detailed in a colonial architectural language.

\subsubsection{Elements}

The front door is a double door with a deity in a panel above the door frame. Traditional elements such as niches and motifs of deities contribute to the resilience of belief systems (Fig. 6). The window is a point of control. Private rooms are spatially organized around the inner courtyard which holds a tulsi plant. Unlike the Agraharam house visibility is increased here of the interior and its objects and permeability is controlled. Two layers of Thinnai offer insulation from the outside in addition to the house being set at a distance from the road. In the Interior the main hall is enclosed by walls from which portraits of ancestors hang. One wall has a niche and for images of local deities form an altar.

\subsubsection{Layering in the interior}

The inside is for women and family and treated simpler and in a different scale with different finishes seen also in the rudimentary columns (Fig. 9), around the courtyard which follow the similar system of layering and spatial hierarchy as in the Agraharam house.

\subsubsection{Spatial variables}

Type 2 maintains status and gender differentiation is used by tools of layering resulting in high insulation of the hall and private spaces followed by categoric differentiation and high values of visibility and permeability from inside the compound showing a tendency to discreetly reveal the interior to the chosen few who are allowed to enter. 


\subsection{House 3 - Type 3}

Type 3 house is represented by the potter's Kasi Rajan's house in Chettinad. Type 3 offers an example of the new "vernacular" with industrial materials to form a new vernacular language. Type 3 is representative of his choices within the context of the vernacular. Type 3 shows the aspect of vernacular architecture which constitutes it as a process. The potter is an established craftsperson known for making Ayyanar horses. Ayyanar is a deity specific to Chettinad. The house evolved from a semi-kaccha structure of local materials of thatch roof and brick walls in mud mortar to a concrete and brick house (Fig. 11). The first house of the potter comprised of three spaces. A front ante space with a cooking alcove and two rooms behind. As his livelihood relies on pottery keeping his pottery safe and dry is his main concern. As the thatch proved to be not watertight the new structure was built with a concrete flat roof, with a terrace used for gatherings and corresponds with the advancement in his stature to becoming a prominent potter. Houses in Chettinad are built for security as often women are left behind while husbands and menfolk travel overseas on business. The Chettinad community has a definitive house form visible in the plan in Fig. 13. The new house of the potter is an adaption of this model on a smaller scale.

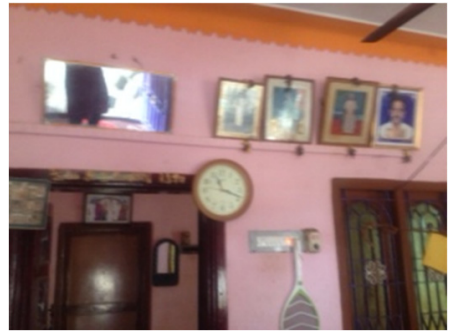

Figure 10: Interior wall with window. (Source: Authors.)

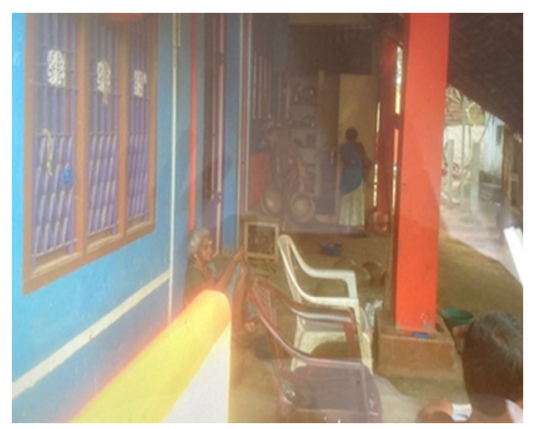

Figure 12: Thinnai area showing window. (Source: Authors.)

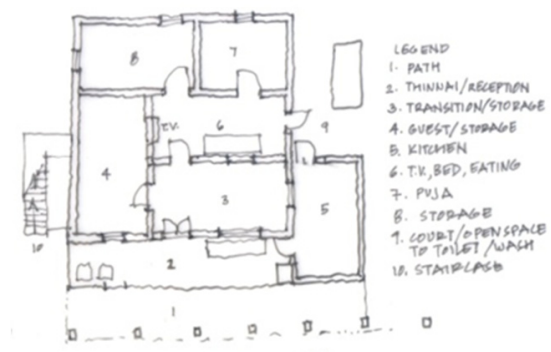

Figure 11: Kasi Rajan house. (Source: Authors.)

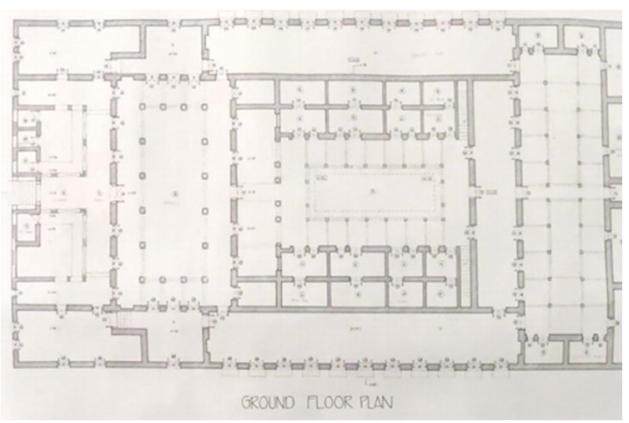

Figure 13: Plan of Chettinad house. (Source: Measi academy of architecture student documentation.) 


\subsubsection{Layering with respect to exterior}

The house interfaces with the street through an open Thinnai unlike the standard Chettinad model of Fig. 13, where security and privacy are paramount. The potter is assisted by his wife and the Thinnai functions as a space for social interaction with outsiders and a space for work.

\subsubsection{Layering with respect to the interior}

The house retains the essential spatial elements of the Chettinad house seen in layering and the use of long rectilinear halls which are transition spaces and makes provisions for small transformations determined by the potter's lifestyle. Layering continues beyond the front door, and the next space in sequence is a transition space of no specific function, followed by the living space and then a series of rooms. Layering of walls insulate through the creation of transition spaces and enforce privacy to the interior and family and private zone. In the potter's house all spaces are used for storage of pots.

\subsubsection{Elements}

The façade wall of his new house has a window and a grille which is painted in many colors (Fig. 12). The Thinnai roof is supported on a concrete column. The doorway is embellished. The façade wall is decorated with colourful paintwork. A painted grille reveals the interior transition space. Windows are present but kept closed (Fig. 11). They have glazed shutters and are designed in a contemporary idiom, unlike Agraharam windows with wooden shutters. They offer no visibility to the interior but suffice as elements of status and are replicated to emulate superficially the style of more affluent Chettinad homes and in this sense are symbolic. They have glazed shutters and are designed in a contemporary idiom, unlike Agraharam windows with wooden.

\subsubsection{Spatial variables}

Categoric differentiation is low. Visibility and permeability are low and transition spaces insulate the interior living spaces. All efforts to afford privacy to the main central living area is manifest in the plan. The Thinnai roof is supported on a concrete column. Technology is used to suggest stature seen in concrete column and roof and the window shutters.

\subsection{House 4 - Type 4}

Type 4 is a Toda hut, the abode of Tribal, buffalo herdsman in the Nilgiris in Tamil Nadu. The Toda hut is a kuccha structure (Figs 14 and 15). The hut is parabolic in shape, it contains a single volume which is entered through a small three feet by three feet opening. The roof and wall merge and the wall can be redefined as a building skin and not comprising the planarity of the other three typologies. Cultural heritage invested in building technology is present in the constructional technique of the roof cum wall and in the front wall which is made of granite slabs.

\subsubsection{Layering}

Toda huts are single volume structures within a compound bordered by a low stone compound wall which defines territory and keeps animals out. A Thinnai area opens to the environment and is the transition between outside and inside. 


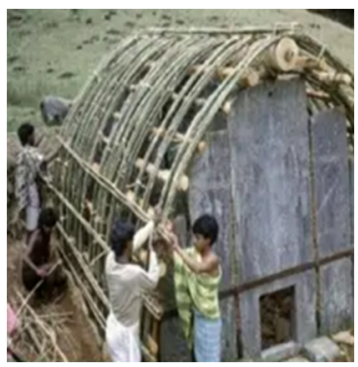

Figure 14: Toda hut. (Source: https://www.ijitee.org/wp.)

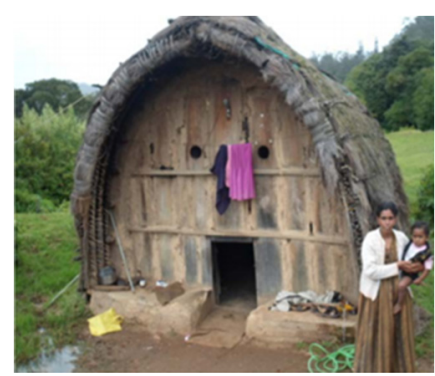

Figure 15: Toda hut showing raised platform for visitors. (Source: http://psrcentre.org/images/extra images/15.\%201312074.pdf.)

\subsubsection{Layering in the interior}

Toda huts are single volume structures and space internally is divided into three main spaces. A raised platform on one side and equipment for milk churning, an activity performed by men which screens a cooking area, reserved for women, in the rear of the hut.

\subsubsection{Elements}

The roof cum wall in bamboo reflects a skill in crafting which has been compared to embroidery for which Toda women are well re-known. The hut facades are often painted with symbols for protection such as the sun, moon floral motifs and buffalo horns. The hut is built by the community and in this respect a social artifact.

\subsubsection{Spatial variables}

Categoric differentiation is specific in the interior in the rear reserved for women. There is no visibility and little permeability in the façade as the huts are located in natural landscape of the Nilgiris Hills and need protection from wild animals.

\section{FINDINGS}

Table 1 show the spatial character of the four houses and further illustrates the significance of the wall in establishing certain preset systems of social relations. The relationship of house to street or environment is seen to be more open in the Agraharam and potters house and more hierarchical in the Marathi house, where it uses depth and extensive layering to maintain exclusivity. Categoric differentiation which is dependent more on gender separation than can be attributed to activities is displayed in all cases. It can be seen that there is a significance of privacy and culture over technology, with the maintenance of certain fundamental value systems. Categoric differentiation is not invested in different types of activity but invested in social hierarchies. The wall acts as a frame for establishing ancestry and thereby constituting status (Fig. 8). Four kinds of walls can be seen-the inhabited wall seen in the niche for deities, the permeable columnar wall and the impermeable compound wall. Colonial construction technologies introduced the masonry pier and high flat ceilings on timber beams called madras terrace roofing. Technological innovation is used to emphasize stature, and security measures and durability as in the case of the potter's house. The potters house shows the vernacular interpretation of modern construction technology within a modified traditional spatial matrix. Modifications are visible, seen in the provision 
of a terrace and its social function and the use of concrete. The hut is built by the community and in this respect a social artifact. The Toda hut exemplifies Rapoport's dictum that vernacular architecture is both process and product. The hut presents an authenticity and cultural rootedness which has been passed on by generations and preserved. As local indigenous materials are used there is constant need for rebuilding and this continues the tradition and reinforces the essence of vernacular architecture. The tectonics of its structure are based on a knowledge system handed down by generations and realized by the community. The door remains a significant element withstanding change and retaining its status as a threshold between realms. Windows are secondary. Changing conditions in the settlements, have resulted in transformations for example in Fig. 19, a compound wall is added to an Agraharam house for security and in Fig. 2 the front wall is used as a surface for political graffiti (Fig. 17), is converted to a shop. There has been a loss of social meaning to the Thinnai. While the vernacular man takes what is available to modify his conditions to survive, the urbanite uses the vernacular architectural language as a source of patterns, which can be used to adorn his house evoking a past in a Post-Modern language of semiotics (Fig. 18 ), where vernacular motifs are used symbolically to highlight entry and create stylistic statements.

\section{CONCLUSION}

Change and transformation is happening at the village level. Demolitions and change have brought new environment and changed the cultural landscape and setting seen in the additional need for security and a degree of inclusiveness (Fig. 19). In the city two directions reference the vernacular. The first as Fig. 18, show contemporary houses where the vernacular element is used to suggest an association of roots and tradition as an attempt to recreate the past with a sense of romanticism and to retain its histories through association.

Table 1: Relation of house to street via its façade through visibility and permeability and spatial social function.

\begin{tabular}{|l|c|c|c|c|}
\hline Spatial variables & Type 1 & Type 2 & Type 3 & Type 4 \\
\hline Visibility-facade & 5 & 2 & 3 & 5 \\
\hline Interior & 1 & 3 & 3 & 1 \\
\hline Permeability & 5 & 2 & 2 & 1 \\
\hline Sequencing & 5 & 5 & 5 & 1 \\
\hline Insulation & 4 & 4 & 4 & 1 \\
\hline Categoric differentiation & 4 & 4 & 3 & 4 \\
\hline
\end{tabular}

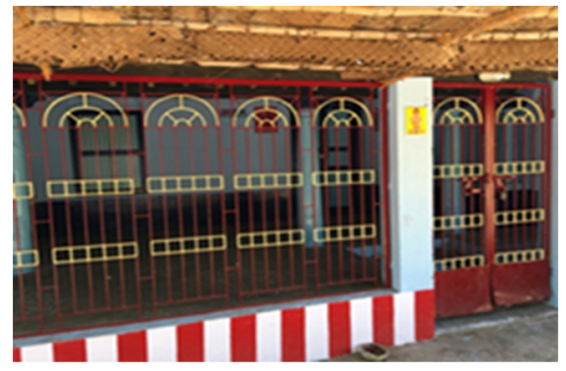

Figure 16: Grilles in thinnai. (Source: Authors.)

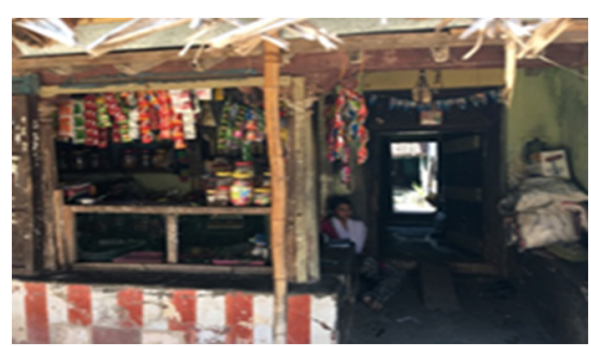

Figure 17: Shop. (Source: Authors.) 


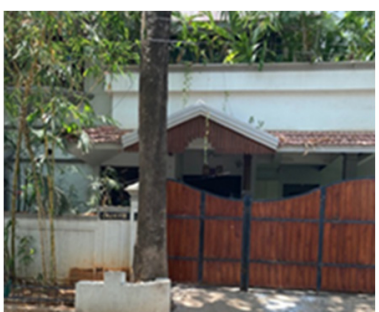

Figure 18: Modern house with traditional entry. (Source: Authors.)

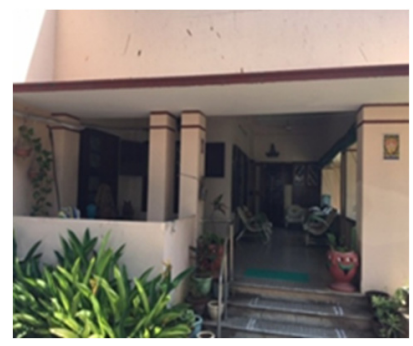

Figure 20: Thinnai in modern bungalow. (Source: Authors.)

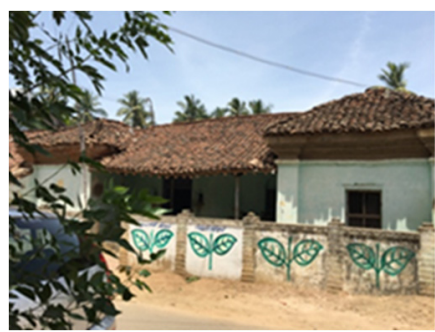

Figure 19: Agraharam house with compound wall. (Source: Authors.)

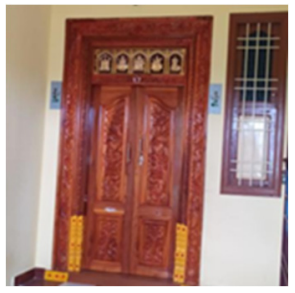

Figure 21: Traditional door. (Source: https://property.sulekha.com/in dividual-houses-villas-forlease/madhavaram-chennai.)

The second as in Fig. 20, shows the vernacular element as motif. Words disjointed from a vocabulary used not in own grammar but symbolically used as a reminder of the past as fragments of the wall. The Thinnai no longer affords a view of the street, its social meaning is modified as a message of welcome, perhaps alluding to its past. The context has changed and its purpose is modified, to serve as a form of imagery of the vernacular. There is a transfer and not transmission of knowledge. Tradition is still held in respect though its manifestations are different and in the current form, as an artifact, social value is removed and what was part of a system of cues in a fabric of tradition woven according to need and symbolic in function now becomes a commodity of economic value representing material value. In this respect heavily carved doors and capitals and columns find their way into newly constructed villas (Fig. 21). What was part of a cultural landscape as material culture lives now in its new form, as a fragment as an object d'art and as a metonym.

\section{REFERENCES}

[1] Glassie, D., Vernacular Architecture, Indiana Press: USA, p. 37, 2000.

[2] Oliver, P., Built to Meet Needs, Architectural Press: UK, pp. 4-18, 2006.

[3] Carter, T. \& Elizabeth, C.C., Invitation to Vernacular Architecture, A Guide to the Study of Ordinary Buildings and Landscapes, The University of Tennessee Press: USA, p. 18, 2005. 
[4] Cooper, I. \& Dawson, B., Traditional Buildings of India, Thames and Hudson: London, p. 11, 1998.

[5] Rapoport, A., House Form and Culture, Prentice Hill: USA, p. 12, 1969.

[6] Rapoport, A., Vernacular Architecture and the Cultural Determinants of Form, Buildings and Society, ed. K. Anthony, Routledge Kegan and Paul: UK, p. 286, 1980.

[7] Pandya, Y., Elements of Space Making, Mapin Publishing Private Ltd.: India, p. 14, 2007.

[8] McMurtrie, R.J., The Semiotics of Movement in Space; A User's Perspective, Routledge, 2017.

[9] Hanson, J., Decoding House, Oxford University Press, 1998.

[10] Beteille, A., The Economic weekly annual number February 1962, Sripuram: A village in Tanjore district. https://www.epw.in/system/files/pdf/1962_14/4-5-6/sripuram_a_ village_in_tanjore_district.pdf. Accessed on: 15 Mar. 2021. 